一論 文—

(日本化学会誌, 1991，（7)，p.995～998）

(C) 1991 The Chemical Society of Japan

\title{
逆ヘキサゴナル型の集合構造をもつポリイオンコンプレックス フィルム中のイオン性ポリマーの分子配向性
}

\author{
（1991 年 2 月 14 日受 理）
}

田口和宏・矢野彰一郎・平谷和 久・箕浦 㶳彦・相 羽誠一

ニトロキシドラジカルでスピンラベルしたポリスチレンスルホン酸ナトリウムと二分子膜形成能をも つ両親媒性物質, 臭化ジメチルジオクタデシルアンモニウムからポリイオンコンプレックスを調製し た。これをコレステロールとともに溶媒キャスト法により製膜して，ミクロな棒状構造からなる非二分 子膜型のフィルムを得た。フィルムの ESR スペクトルは磁場の方向によって異なるパターンを示し た。フィルムの一軸延伸によるスペクトルの変化よりポリマーの長軸は, フィルム中のミクロな棒状構 造と同様に，フィルム面に対して垂直に配向していることが明らかとなった。これらの結果から非二分 子膜フィルムのミクロな棒状の分子集合体は逆へキサゴナル型に近い構造であり，ポリマーは棒状構造 の中心の親水性部に沿って直線的に広がっていることが推察された。

\section{1 緒言}

二分子膜形成能をもつ両親媒性化合物とイオン性ポリマーとの ポリイオンコンプレックス (Polyion complex, 以後 PIC と略称 する）をキャスト製膜すると, 通常, 図 1 (c) の上らな配向し た多層の二分子膜構造が形成される(1) 。市ころがこの PICをこ レステロールなどの添加物とともに製膜すると,'PIC の集合構造 は二分子膜型からミクロな棒状構造からなる非二分子膜型に变化 することが見いだされた6゙ 8)（図 $1 \mathrm{a}$ )。しかも，その棒状構造は フィルム面に垂直な方向にいちじるしく配向している。このよう な高い異方性をもつフィルムが特別な操作も必要とせずキャスト 製膜の過程で自発的に生じる現象は, 通常の高分子には見られな いものであり，きわめて興味深い。このような配向フィルム中の 使用したイオン性ポリマーの存在状態, とくにその分子配向性に 興味がもたれる。低分子である両親媒性物質の配向性はX線回折 により比較的容易に決めることができる。しかし、イオン性ポリ

工業技術院製品科学研究所, 305 つくば市東

1) T. Kunitake, A. Tsuge, N. Nakashima, Chem. Lett., 1984, 1783.

2) Y. Okahata, K. Taguchi, T.Seki, J. Chem. Soc., Chem. Commun., 1985, 1122.

3) K. Taguchi, K. Hiratani, Y. Okahata, ibid., 1986, 364.

4) K. Taguchi, S. Yano, K. Hiratani, N. Minoura, Y. Okahata, Macromolecules, 21, 3336(1988).

5）田口和宏, 矢野彰一郎, 平谷和久, 箕浦憲彦, 日化, 1990, 1373 .

6) K. Taguchi, S. Yano, K. Hiratani, N. Minoura, H. Umehara, Macromolcules, 22, 4140(1989).

7) K. Taguchi, S. Yano, K. Hiratani, N. Minoura, ibid., 印刷中.

8）田口和宏, 矢野彰一郎, 平谷和久, 箕浦密意, 日化, 1991, 247.
マーの配向性はX 線回折などでは直接推定することは困難であ る。そこで, 本研究ではスピンラベルしたイオン性ポリマーから 得られるPIC の ESR スペクトルの異方性からポりマーの配向性 を推定することとした。さらに，イオン性ポリマーの分子配向性 から非二分子膜の集合構造について考察した。

\section{2 実験方法}

\section{1 フィルムの調製}

p-スチレンスルホン酸ナトリウムとメタクリル酸の共重合物 (メタクリル酸含量 $5 \mathrm{~mol} \%$ 以下）のメタクリル酸残基にスピン プロープ, 4-アミノ-2, 2,6,6-テトラメチルピペリシンン-1-オキシ

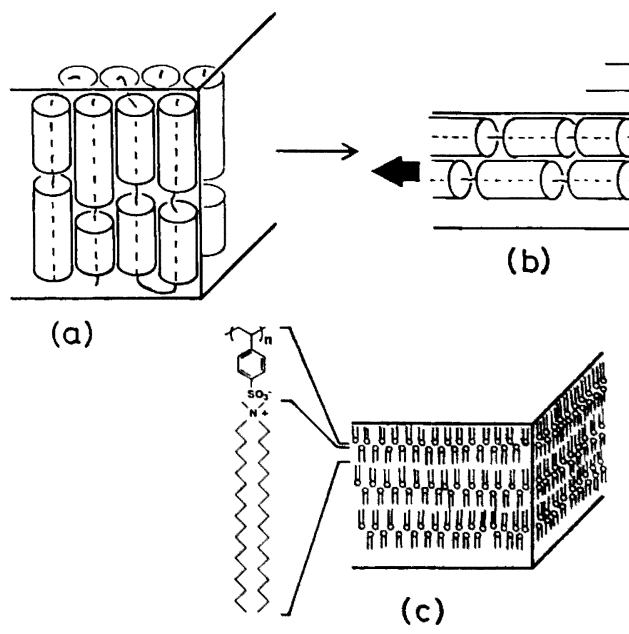

Fig. 1 Schematic illustrations of non-bilayer film and multi-bilayer film.

(a) a non-bilayer film consisted of micro-rods,

(b) a uniaxially-stretched non-bilayer film,

(c) a multi-bilayer film. 
ド（以下 4-アミノ-TEMPO と略記する）を水溶性のカルボジイ ミドを用いて結合させ，スピンラベルしたポリスチレンスルホン 酸を得た9)。第四級アンモニウム塩型の両親媒性化合物, 臭化シ メチルジオクタデンルアンモニウムとスピンラベルしたポリスチ レンスルホン酸ナトリウムから常法により PIC を得た ${ }^{11 \sim 6) 。 こ の ~}$ PIC とコレステロール（重量比 $80 ： 20 ）$ のクロロホルム溶液か らキャスト製膜した。真空乾燥後, $60^{\circ} \mathrm{C}$ の温水中で 10 分間熟成 を行った。この PICフィルムから $300 \%$ の一軸延伸フィルムを 調製した。延伸は $50{ }^{\circ} \mathrm{C}$ の水中で約 $100 \% / \mathrm{min}$ の速さで行った。

\subsection{ESR スペクトルの測定}

電子スピン共鳴スペクトルの測定には Varian E-line 電子スピ ン共鳴装置 $(9 \mathrm{GHz})$ を用いて $20^{\circ} \mathrm{C} て ゙$ でった。非二分子膜フィ ルムを石英製の ESR 用管に挿入し，測定に支障のない量の水で 湿らせた状態で，フィルム面が磁場の方向に対して平行または垂 直になるよらにしてスペクトルを得た。

\section{3 結果と考察}

\section{1 ポリマーの分子配向}

スピンプローブでラベルした非二分子膜フィルムのスペクトル の方向性とその延伸フィルムのスペクトルを比較することによ り, 非二分子膜中のイオン性ポリマーの配向を推定した。もし図 1 (a) のミクロな棒状構造が存在し,ポリマーの配向性がその棒 状構造の配向性の影響を受けているとすれば，ESR スペクトル に異方性が現れることが予想される。一方, 二分子膜フィルム （図c）ではポリマー主鎖は二分子膜フィルムの面にそって任意 の方向を取りらるためスペクトルの方向性は小さいか, または存 在しないであるらと考えられる。また, 非二分子膜中のポリマー が配向性をもっていればフィルムの延伸処理によりスペクトルの パターンが変化すると予想される。

磁場の方向に対して非二分子膜フィルムの面が平行または垂直

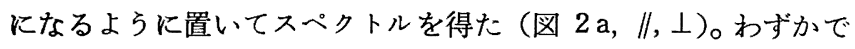
あるが両スペクトルには差異が見られた。さらにこの非二分子膜 フィルムを温水中で $300 \%$ の一軸延伸処理を施し，ESR スペク トルの方向性の変化を観察した (図 $2 \mathrm{~b}$, 便宜的に延伸方向を $\mathrm{Y}$ 軸とした)。延伸によりスペクトルのパターンは変化した。磁場 の方向と一軸延伸の方向を一致させて得られたスペクトル (b// $\mathrm{Y})$ は，磁場の方向とフィルムの面を一致させて得られた非二分子膜
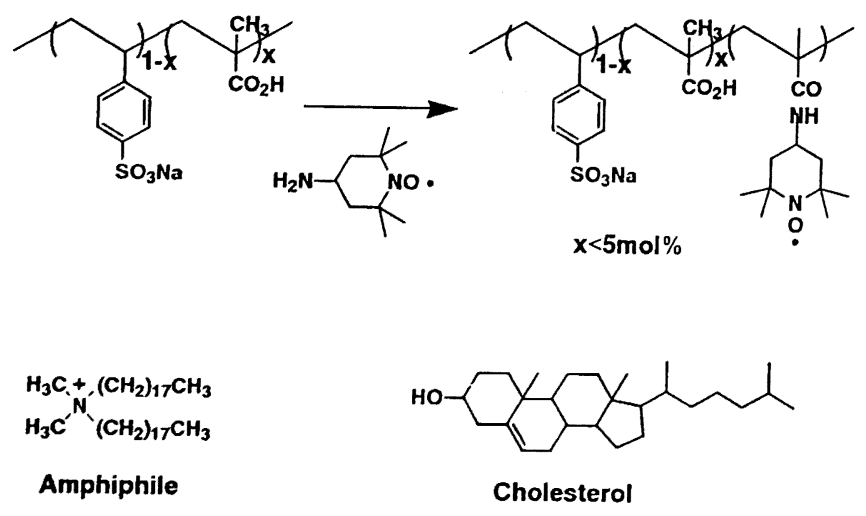

9）田口和宏, 矢野彰一郎, 平谷和久, 箕浦害彦, 日化, 1991 990.
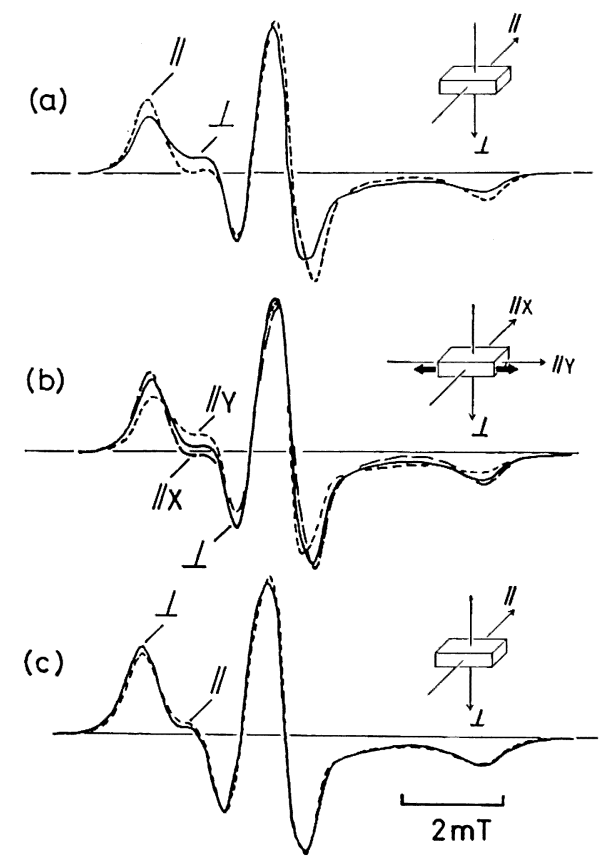

Fig. 2 ESR spectra of the polyion complex films labeled with a spin probe

(a) a non-bilayer film, (b) a uniaxially-stretched non-bilayer film. (c) a multi-bilayer film.

フィルムのパターン $(\mathrm{a} \perp)$ に似ており, また磁場方向と一軸延伸

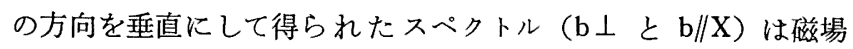
の方向とフィルム面を平行にして得られた元のフィルムのスペク トル（a/l）と類似している。

延伸フィルム中のポリマーの長軸は一軸延伸の方向と同方向で あること, 非二分子膜フィルムのスペクトル $(\mathrm{a} \perp)$ が, 延伸フィ ルムのスペクトル (b// Y $)$ に対応していることを考え合わせる と, 元の非二分子膜フィルム中のポリマーの長軸はフィルム面に 垂直な方向に配向していることが結論される。

ESR スペクトルから見た非二分子膜フィルムの異方性は大き くはない。しかし，ESR スペクトルの結果は非二分子膜フィルム 中のポリマーの配向性が小さいこと必ずしも意味するものではな い。もしスピンラベルとして用いたニトロキシドラジカルがフ 1 ルム内で一定の方向に完全に固定されているのならスペクトルは 磁場の方向に大きく依存するはずである。しかし，ポリマーはそ の長軸方向を軸とする回転の自由度をもち，またスピンプローブ (TEMPO) はいくつかの単結合を介してポリマー主鎖に結合さ れているために，比較的高い回転と方向の自由度をもっている。 またポリマーの主鎖も種々の配座をもつであろう。その結果, 非 二分子膜中のポリマー主鎖の長軸は全体として高い方向性をもっ ていたとしても，スペクトルの磁場の方向に対する依存性は小さ いものとなろう。実際, 非二分子膜フィルムの磁場の方向による スペクトルの違いは, $300 \%$ の一軸延伸フィルムのスペクトルの 場合と同程度であることから，ポリマーはフィルム面に垂直な方 向にかなりよく配向しているものと考えられる。

な拈二分子膜フィルムのスペクトルの磁場の方向に対する依存 性はほとんどなく, 非二分子膜フィルムの二つのスペクトルの平 均に近かった（図 $2 \mathrm{c}$ )。 


\section{2 非二分子膜フィルムの棒状構造と逆へキサゴナル構造}

著者らはすでに，両親媒性化合物の PIC が非二分子膜型の集 合構造を形成するための分子構造上の必要条件を検討した。その 結果, このような非二分子膜型の集合構造の形成はかなり一般的 な現象であり，一定の分子構造上の条件を満足すればよいことが 明らかになった8)。すなわち，二分子膜型フィルムを形成する両 親媒性化合物の PIC が非二分子膜型の集合構造に変化するため には, コレステロールのような蹯水性部が親水性部にくらべて分 子容積が大さい，いわゆるコーン型の分子を添加すればよいこと が明らかとなった。PIC の非二分子膜型集合構造が形成されるた めの条件は, 天然のリン脂質, シアシルグリセロールホスファチ ジルェタノールアミン (PE) がつくる非二分子膜型の逆へキサゴ ナル相の形成のための添加物や PE の化学構造上の条件と類似し ている10 16)。

非二分子膜型の集合構造をもつ PIC のX線回折はきわめて単 純なパターンであるため, 直接そのミクロな棒状構造を決定する ことはできなかった。しかし，本研究で明らかになった PIC 中 のポリマーの配向性，および上で述べた非二分子膜集合構造の形 成条件を総合することにより，PIC の非二分子膜型の集合構造に ついて次のよらに推察することができた。

コレステロールの添加によって生じた特異な集合構造は, 二分 子膜のような層状の長周期構造をもつものであって, その層状構 造が通常の二分子膜フィルムとは配向が 90 度異なるように発達 したものとすると,イオン性ポリマーがフィルム面に垂直に配向 するとは考えにくい。一軸延伸によるX線回折の結果から推定し たよらに,フィルム面に垂直に配向性したミクロな棒状構造を想 定すれば，ポリマーの垂直方向への配向を理解しうる。両親媒性 化合物のイオン性基はポリマーのイオン性基の近傍に存在しなけ ればならないこと，X線回折と DSC の結果からは両親媒性化合 物の長鎖アルキル基の二分子膜型の配列は完全に失われていない こと，ミクロな棒の直径に相当すると考えられる小角領域の X線 回折像はかなり鋭いことなどから棒の内部構造もかなり高い規則 性をむつことが想像される。これらのことを考虑すると, 図 $3 \mathrm{c}$ に示すよらに棒状構造の中心部に直線状に伸びたポリマー分子が 存在し, このポリマーとイオン対を形成した両親媒性物質がポリ マーを取り囲むようにして形成された棒状構造がモデルとして考 えられる。このモデルは，以後に述べるようにコーン型の添加物 による疎水性部の分子容積の増大を受け入れることができるモデ ルでもある。棒状の中心以外にポリマーが存在するモデルではポ リマーの高い配向性を説明できないであろう。

このモデルは PE の逆へキサゴナル構造と基本的に同一であ る。しかし非二分子膜型の PIC フィルムでは, PE の逆へキサゴ

10）野島庄七，砂本順三，井上圭三編，“リポソーム”，南江堂 (1988).

11) P. R. Cullis, B. De Kruijff, Biochim. Biophys. Acta, 559, 399(1979).

12) J.M. Boggs, D.Stamp, D.W. Hughes, C. M. Deber, Biochemistry, 20, 5728(1981).

13) P. R. Cullis, B. De Kruijff, Biochim. Biophys. Acta, 513, 31(1978).

14) C.P.S. Tilcock, P. R. Cullis, ibid., 684, 212(1982).

15) T.M.Madden, P. R. Cullis, ibid., 684, 149(1982).

16) P. R. Cullis, B. De Kruijff, ibid., 507, 207(1978).

17) P. R. Cullis, B. De Kruijff, ibid., 559, 399(1979).

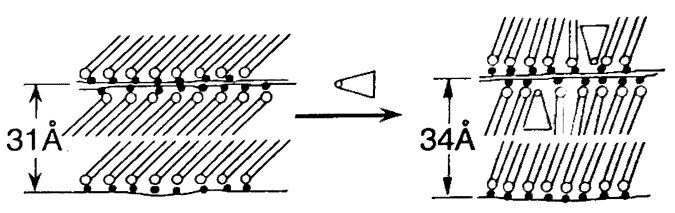

(a)

(b)

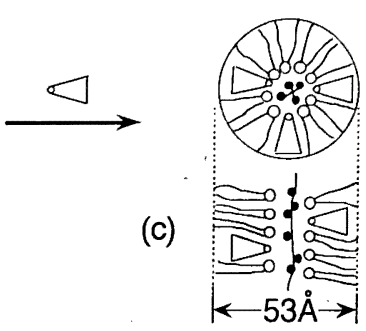

Hydrophilic Group

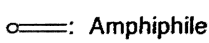

$\square$ : Cholesterol

Hydrophobic group

Fig. 3 Effect of a cone shape additive (cholesterol) on the multi-bilayer(dimethyldioctadecylammonium-poly(styrenesulfonate)) and inverted hexagonal type rod-like assembly ${ }^{6}$ ) $)$

(a) a multi-bilayer, (b) a multi-bilayer containing a small amount of additive $(5 \%$ cholesterol), (c) a inverted hexagonal type $\operatorname{rod}(20 \%$ cholesterol).

ナル相で観察される，棒状構造の六方最密充填に由来する高次の 回折が見られない。また非二分子膜フィルムは，非二分子膜型の 集合構造をつくるコレステロール含量においても二分子膜のゲ ルー液晶相転移に相当する温度で小さいながらもDSC の吸熱ビ ークが観察される。このことは PIC の非二分子膜構造では, 一 部分に二分子膜型の構造が残っていることを示唆している。おそ らく PIC 中の棒状構造の集まり方は，PE の逆へキサゴナル相ほ ど完全ではないために，高次な回折が現れなくなったものと考え られる。

添加物によって PIC の集合構造が二分子膜型から非二分子膜 型に変わる原因は，PE の逆へキサゴナル相の形成に対する添加 物の効果と同じように考えることができる。二分子膜では両親媒 性物質の長鎖アルキル基は，二分子膜の法線方向に対してかなり の傾きをもっている（図 $3 a$ )。柾水性部が親水性部に対して相対 的に大きなコーン型の分子が添加されたとき，添加物が少量であ れば二分子膜が厚くなることによって相対的に蹯水性部分が増大 し，添加物の影響は吸収され，二分子膜構造は維持される ${ }^{18)}$ (図 $3 \mathrm{~b})$ 。さらに多量のコーン型分子が添加された場合には，逆へキ サゴナル型の構造に変化し，より大きな䟱水性部が実現されるこ とによって添加物が受け入れられるものと考えられる（㕯 $3 \mathrm{c}$ ）。

逆へキサゴナル構造は, 塩化ジメチルジオクタデシルアンモニ ウムー水系ですでに確認されている(191201。疎水性の高い1-オク夕 ノールをこの系に添加すると，系が眯水的になり水相に対して凹 な集合構造をつくりやすくするために，二分子膜型の集合棈造が 逆へキサゴナル棈造に変化するとされている。コレステロールの 添加による PIC の非二分子膜構造の形成も系の疎水化の她果に

18) T.Kajiyama, A.Kumano, M. Takayanagi, I. Okahata, T. Kunitake, Chem. Lett., 1979, 645.

19）国枝博信, 日化, 1977, 151.

20）中坦正幸, “膜学入門”，喜多見書閣（1978）。 
よっても考えることができる。

\section{4 結 論}

ポリマーをスピンラベルして調製した非二分子膜型のフィルム の ESR スペクトルの異方性から, フィルム中のポリマーの分子 配向を推定することがでさた。ポリマーの長軸は, 非二分子膜フ ィルムのミクロな棒状構造と同様に, フィルム面に対して垂直に
配向していることが明らかになった。この結果は PIC の非二分 子膜フィルムがフィルム面に対して垂直に配向した棒状の分子集 合構造を支持するものであり，また天然のリン脂質でみられる逆 へキサゴナル相に類似した棒状構造によって理解できた。これら の結果は，非二分子膜フィルムの特異な分子集合構造と巨視的な 配向性を利用した機能材料を構築するに際して有用な情報となる ものと期待される。

\title{
Molecular Orientation of Ionic Polymer in a Polyion Complex Type Nonbilayer Film with an Inverted Hexagonal Phase
}

\author{
Kazuhiro Taguchi*, Shoichiro Yano, Kazuhisa Hiratani, Norihiko Minoura \\ and Sei-ichi Aiba
}

Industrial Products Research Institute; Higashi, Tsukuba-shi 305 Japan

\begin{abstract}
A polyion complex was prepared from a bilayer forming amphiphile, dimethyldioctadecylammonium bromide, and poly(sodium styrenesulfonate)labeled with nitroxide radical on a small amount of methacrylate residue in the polymer. A nonbilayer film comprised of micro-rods was prepared by usual solvent cast of the polyion complex and cholesterol $(80: 20(\mathrm{w} / \mathrm{w}))$. The ESR spectra of the film depended on the direction of applied magnetic field during measurement. Each spectra was changed by uni-axially stretch of the film due to the alternation of the molecular axis of the ionic polymer. The change in the spectra suggested that the longitudinal axis of the ionic polymer was perpendicular to the film surface in a similar manner as the micro-rod. The orientation of the polymer molecule supports an invertedhexagonal type model in which the molecule of ionic polymer would extend linearly along the hydrophilic core of the rod.
\end{abstract}

